\title{
一种新型肢体活动辅助用具在经桡动脉行冠状动脉 介入治疗后的应用
}

\author{
Application of a New Type of Limb Mobility Aids After Coronary Artery Interventiona Treatment \\ Via Radial Artery \\ 卢梅 黄鹏林 潘玲 唐俊 何斌
}

Mei Lu Penglin Huang Ling Pan Jun Tang Bin He

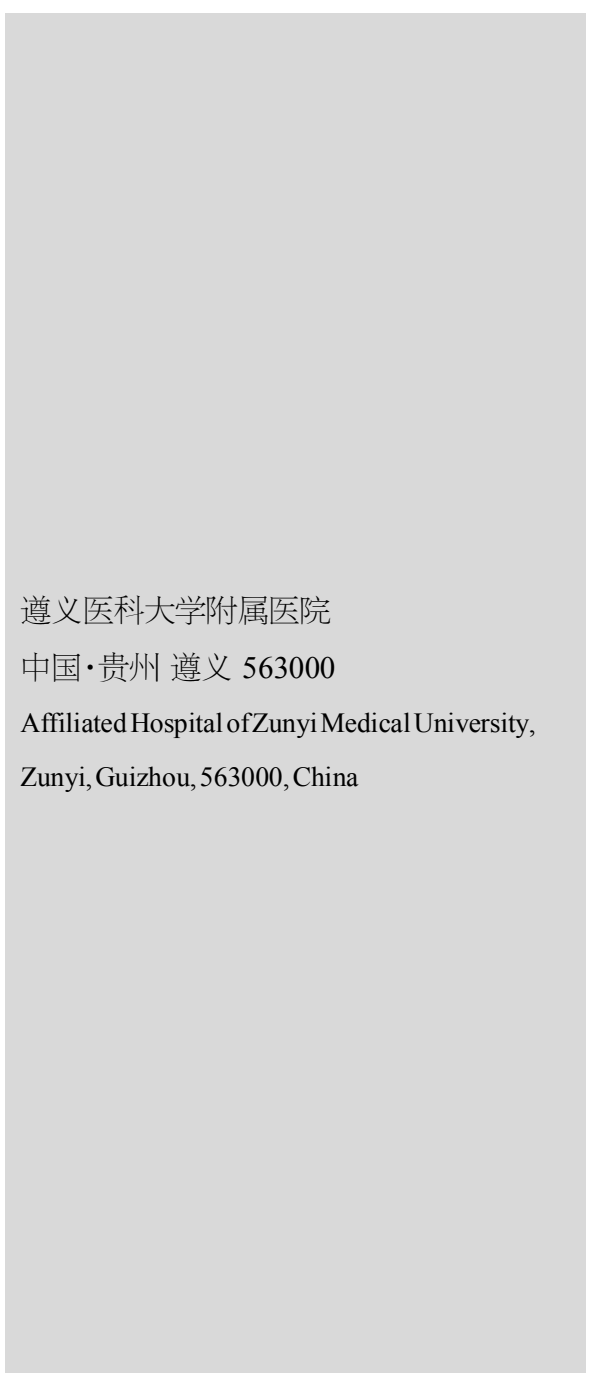

【摘 要】目的: 探讨冠状动脉倨样硬化性心脏病(冠心病)患者经桡动脉行冠状动脉介入 治疗术后, 术侧肢体应用肢体活动辅助用具的护理效果以及并发症发生的情况。方法: 选取 2009 年 11 月 1 日一 2020 年 5 月 1 日我科行经桡动脉介入治疗的 100 例冠心病患者作为 研究对象, 将其随机分为观察组和对照组, 观察组介入治疗术后术肢在常规护理的基础上 应用新型体位垫进行术后护理, 对照组采用传统方法进行术后护理。结果: 观察组患者介入 治疗术后术侧上肢疼痛、麻木感、术肢前臂的肿胀例数均低于对照组, 患者术肢舒适度及满 意度显著高于对照组。结论: 应用新型肢体活动辅助用具对经桡动脉行冠状动脉介入治疗 患者术肢的护理, 能减轻患者介入治疗术后术侧肢体疼痛、麻木感和肿胀度, 降低出血风 险,提高患者术肢舒适度,值得推广应用。

【Abstract \Objective: To investigate the nursing effect and complications of limb movement aids on patients with coronary atherosclerotic heart disease (coronary heart disease) after coronary intervention through radial artery. Methods: 100 patients with coronary heart disease who underwent radial artery interventiona treatment in our department from November 1, 2009 to May 1, 2020 were selected as the research object, and they were randomly divided into an observation group and a control group. On the basis of routine nursing, the limbs were applied with new posture pads for postoperative care, and the control group used traditional methods for postoperative care. Results: Patients in the observation group had lower upper limb pain, numbness, and swelling of the forearm in the surgical side after interventiona treatment than those in the control group. The patient's limb comfort and satisfaction were significantly higher than the control group. Conclusion: The use of new limb mobility aids fin the nursing of patients undergoing coronary artery interventiona treatment through the radial artery can reduce the pain, numbness and swelling of the limbs, reduce the risk of bleeding, and improve the comfort of the patients, it is worthy of popularization and application.

【关键词】新型肢体活动辅助用具; 经桡动脉介入术; 临床应用

【Keywords 】new type of limb mobility aids; transradial artery intervention; clinical application 【DOI】10.36012/pmr.v2i2.1829

\section{1 引言}

桡动脉入径的经皮冠状动脉介入治疗 (Percutaneous

【作者简介】卢梅(1987 ), 女, 汉族, 贵州遵义人, 主管护师, 学士学 位, 从事冠心病介入治疗研究。
Coronary Intervention,PCI)目前已经成为国际首选的 PCI 人径 方式, 其具有创伤小、出血少、并发症少、患者依从性好、恢复 快等优势, 而且随着介入器械和技术的进步和应用, 介入治疗 的成功率显著提高。与经皮股动脉穿刺这一传统途径相比, 经 皮桡动脉冠状动脉介人治疗（Trans-radial Coronary Inter- 
vention, TRI) 是目前冠心病 PCI 治疗较为理想的途径。TRI 术 后常采用绷带加压止血法对穿刺处进行止血, 由于腕部制动 且受压, 加之患者处于过度紧张、焦虑状态, 注意力多集中于 疼痛的穿刺处, 不愿意活动手指, 对相关护理措施或健康教育 的理解与配合度低, 发生肿胀、疼痛、麻木、出血等问题仍较为 常见 ${ }^{[1]}$ 。抬高肢体可借助重力作用, 利于静脉回流, 辅以掌指适 度的活动等, 能有效减轻肢体的肿胀, 随之也减轻对腕部神经 的压迫, 起到缓解疼痛、麻木感的作用 ${ }^{[2]}$ 。使用新型肢体活动辅 助用具后有效提升了患者 TRI 术后抬高上肢依从性，有效减 缓了术肢的疼痛与肿胀, 从而改善了患者不良情绪、睡眠质量 及舒适度, 同时也提高了护士的满意度。

\section{2 材料与方法}

\section{1 材料}

海绵垫(倾斜设置的垫块及凹槽)、透气棉布。

\section{2 制作方法}

多边形海绵垫枕包括倾斜设置的垫块、横向设置的底板 和方形凹槽、坚向设置的三角形垫块, 坚向设置的三角形垫块 与凹槽的夹角为 $165^{\circ}$, 竖向设置的三角形垫块与底板的夹角 为 $30^{\circ}$, 表面用透气棉布包裹, 可拆洗消毒(见图 1)。

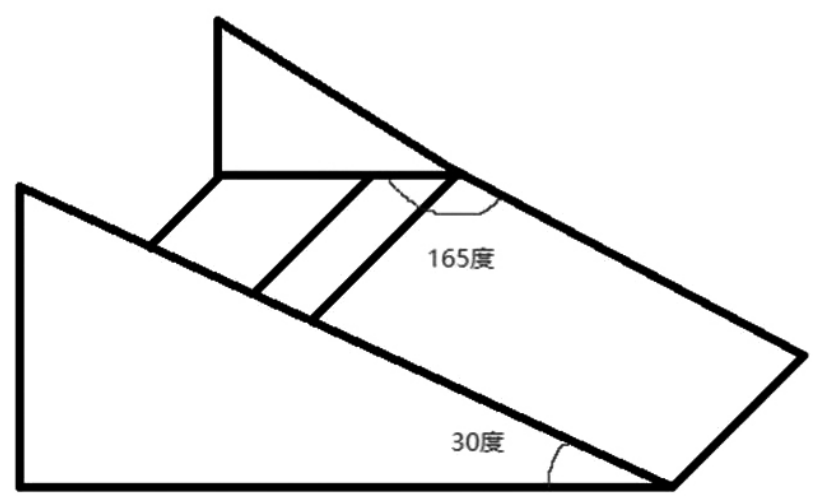

图 1 多边形海绵垫枕

\section{3 使用方法}

患者术后返回病房, 评估术区情况, 向患者解释并取得配 合。在新型肢体活动辅助用具上垫一块无菌治疗巾, 将患者前 臂放在设置的垫块上, 手背放在方形凹槽内, 可避免移动并提 高舒适度。教患者手指做握拳松拳的动作, 或者手握一圆形小 球, 可有效缓解肢端的肿胀及疼痛感。

\section{3 临床应用}

\section{1 对象}

选择 2019 年 11 月 1 日一-2020 年 5 月 1 日我科经桡动脉 行冠状动脉介人术的 100 例冠心病患者作为研究对象, 将其 随机分为观察组和对照组, 各 50 例。

纳入标准:经桡动脉行冠状动脉介人术后病情稳定, 意识 清楚,无言语功能障碍, 无严重的肝肾功能疾病。

\section{2 研究方法}

观察组术后给予新型体位垫抬高, 并制动术侧肢体, 对照 组采用传统的方法,给予术肢抬高。

\section{3 统计学方法}

采用 SPSS20.0 统计学软件对数据进行处理, 计数资料采 用 $\mathrm{t}$ 检验, 以 $P<0.05$ 为差异有统计学意义。

\section{4 结果}

观察组患者介入治疗术后术侧上肢疼痛、麻木感、术肢前 臂的肿胀例数均低于对照组, 患者术肢舒适度及满意度显著 高于对照组。

\section{5 结语}

近年来,介入手术治疗飞速发展, 经皮冠状动脉介入治疗 可以快速使闭塞的血管再通，挽救缺血心肌，防止左心室重 构,保护左心室收缩功能,改善患者的预后, 目前已成为冠状 动脉籿样硬化性心脏病(冠心病)治疗的重要手段之一 ${ }^{[3]}$ 。然 而,随着手术量的增加,术区并发症也在增加。新型肢体活动 辅助用具的使用, 不仅有效减缓了患者术肢的疼痛与肿胀, 而 且能降低并发症的发生, 降低患者住院时间, 降低医疗费用, 增加了患者对医院、医务人员的信任, 从而提高了患者的满意 度, 值得推广临床应用。

\section{参考文献}

[1]张文杰,周栋雯,李金金,等.介人上肢垫在经桡动脉冠状动脉介人 治疗术后的应用[J].中华护理杂志,2013,48(7):636-637.

[2]姚思佳,任家武.前臂桡动脉腕掌支的应用[D].衡阳:南华大学, 2011.

[3]陈丽萍,吴少琼,王丽娜.针对性护理干预对经皮桡动脉冠心病 介人术后并发症的影响[J].国际医药卫生导报,2012,18(3):398-400. 